\section{Bureaucracy savings should go to research}

We believe that there is a pressing need to cut the cost of bureaucracy in universities and to channel those savings into research.

In Australia, for example, spending by the top ten research universities rose from almost Aus $\$ 6$ billion in 2003 (US\$3.9 billion at the time) to more than Aus $\$ 10$ billion in 2010 (2010 US $\$ 9.2$ billion), but only $30 \%$ of this was allocated to the employment of academics. This is worrying, given that a university's main objectives are research and teaching. Almost as much (26\%) was spent on non-academic salaries; the rest went on assets such as branding, buildings and equipment. Similar spending patterns can be found in UK and US universities.

As well as the restrictive effect on academic appointments, this bureaucratic burden adversely affects scholarly output, with academics spending too much time on paperwork and internal meetings. Some must even forgo research altogether as they become swamped by administrative tasks.

Senior university officials should make radical changes to the spending habits of institutions, despite the likely resistance that would come from non-academics. Australian academic Alan Trounson, president of the California Institute for Regenerative Medicine (CIRM) in San Francisco, has shown that such changes are feasible. In 2009, he pledged to spend less than $6 \%$ of CIRM's revenues on administration costs, a figure that is better than for most commercial firms (see go.nature. com/ummgkb). As of February 2011, CIRM had spent $4.1 \%$ on administration (see go.nature. com/ntv5he).

Administration should enable universities to run efficiently, but it must be streamlined. A bold university that reforms its cost structures will have more money to spend on its core business. Nicholas Graves, Adrian G. Barnett Queensland University of Technology, Queensland, Australia.

n.graves@qut.edu.au

\section{Ireland: a strong knowledge economy}

I take issue with Mojgan Naghavi's and Derek Walsh's critique of Science Foundation Ireland (SFI; Nature 476, 399; 2011). Ireland has moved steadily up the country rankings of research performance and is now in the top 20, according to Thomson Reuters Essential Science Indicators.

This success is largely a result of the rigour of the international competitive review process implemented by the SFI since 2000 , intended to select only the best science for funding.

This strategy has been purposefully carried out by successive governments against a worsening domestic and international economic backdrop, exemplifying a consistent, considered and longterm approach to research in Ireland.

Also, the SFI does not directly recruit researchers. Rather, it allows researchers and host institutions to compete for research funding.

The foundation has made a significant investment in research infrastructure over the past decade. However, more than $75 \%$ of state investment has been, and continues to be, in the scientists themselves. The budget of the SFI in 2011, far from fading, was increased by $7 \%$ at a time when most public spending has been significantly curtailed.

Naghavi and Walsh's suggestion that Ireland is among nations with "ill-planned knowledge-economy ventures" is at odds with its impressive statistics on inward investment in research and development, and the role of this in enhancing exports, increasing employment and adding value to Irish firms (see, for example, www.forfas.ie and www.idaireland.com).

Graham Love Science

Foundation Ireland, Dublin, Ireland.

graham.love@sfi.ie

\section{Ireland: global links pay off}

I contend that Mojgan Naghavi's and Derek Walsh's claim of cronyism in the Irish university system is unfounded (Nature 476, 399; 2011).

Excellence in research and teaching are the criteria for recruitment. The openness of our recruitment system is evident: more than 35\% of doctoral candidates and 35\% of postdoctoral researchers in Ireland are from overseas, and $26-42 \%$ of permanent academic staff across the seven Irish universities are international. They add strength to the cohort of tenured senior investigators, which is essential to the health of any advanced research system.

Ireland is building up its research base through a longterm plan to attract and retain the best talent and to develop its research infrastructure. Progress began in the 1990s as a result of investment from the European Union's Structural Funds and Framework Programmes for Research and Technological Development, which led to more international collaborations. Such investments are indicative of genuine strategic intent by Ireland's government and universities.

National policy initiatives have emphasized the need to invest in research as an integral part of economic development and, more recently, recovery (see, for example, go.nature. $\mathrm{com} / \mathrm{kwfpct}$ ). These have been implemented by consistent state and philanthropic investments in research, and by the ability of Irish universities to compete successfully for international research funds. As a result, the country now has state-of-the-art laboratories and research centres (see, for example, go.nature.com/ qzfaed) and, crucially, talented scientists to staff them.

Conor O'Carroll Irish

Universities Association, Dublin, Ireland.

conor.ocarroll@iua.ie

\section{More freedom for Turkish science}

The future of science in Turkey is being undermined by recent government actions (Nature 477, 131; 2011). Academic autonomy is crucial if Turkish scientists are to flourish at home and abroad. A partisan approach will not advance Turkey's society or stop the brain drain.

The government should take advantage of the Turkish economy's latest positive indications and increase the country's modernization assets. At present, just $0.6 \%$ of gross domestic product is invested in research and development.

To improve research morale, Turkey's government needs to reverse the centralization of science policy-making and give more power to scientific committees. These should be made up of competent researchers, who understand their own needs better than officials. It should reform scientific councils to allow them to operate democratically and with transparency, and abandon partisan legislation.

These measures would improve the credibility of science in society and help to educate a fatalistic and irrational public. Albert Einstein pointed out that imagination is more important than knowledge: the Turkish scientific community is simply seeking the prerogative and freedom to imagine.

Caghan Kizil Technical University Dresden and DFG Center for Regenerative Therapies, Dresden, Germany. caghan.kizil@crt-dresden.de 